\title{
Research on Education Reform in Engineering Management Specialty Based on BIM Technology
}

\author{
Daolin $\mathrm{Si}^{1 \text {, a }}$ \\ ${ }^{1}$ School of Management Engineering, Jinan Engineering Vocational Technical College, Jinan \\ 250200,China \\ asd198532@163.com
}

Keywords: Building Information Modeling(BIM); Engineering management specialty; BIM course; Education reform

\begin{abstract}
Through the present situation of BIM course of engineering management specialty in colleges and universities, the principles of BIM course of engineering management specialty is analyzed, the core ability of training the professional personnel of engineering management specialty based on BIM technology is studied, some suggestions for the course of engineering management specialty based on BIM technology is proposed, and it can provide reference and basis for the education reform of BIM in engineering management specialty.
\end{abstract}

\section{Introduction}

In recent years, with the development of our country's economy, new technologies, new processes, new materials and new specifications have springing up in the construction industry, especially the building information model (BIM) technology in engineering management[1].

What is BIM? Building Information Modeling. It is a multi-dimensional model information integration technology developed on the basis of $\mathrm{CAD}$ (Computer Assisted Design) technology. It is the digital carrying and visualization expression of engineering physical characteristics and functional characteristics information[2]. The real information through the digital information simulation project has, this information includes 3D geometry information and a lot of non geometric information, such as materials, quality, price and schedule, to establish the information model as the basis for the project decision and sharing of information resources[3].

The construction projects with BIM technology have produced a series of effects, such as the improvement of construction quality and labor productivity, the reduction of rework and waste, the saving of construction cost and the improvement of economic benefits of construction enterprises. The vigorous development of BIM technology has a revolutionary influence on the construction industry, which will lead the construction industry to enter the new BIM era, which requires a large number of BIM technical engineering management talents, which also requires universities to train a large number of engineering management professionals to match. In order to meet the needs of the construction market for engineering management talents in the new era, education reform in engineering management specialty based on BIM technology is more urgent[4].

\section{Current Status of BIM course in Engineering Management Specialty}

Through the investigation found that in the current engineering management in Colleges and universities, different people have a different point of view on the application of BIM technology, which can be roughly divided into two kinds: some people think that BIM is a kind of software, or just a kind of new technology of engineering management, BIM will not bring much impact to the engineering management professional teaching[5]. Others think that the vigorous development of BIM has a huge impact on the construction industry. They think that the BIM era is really coming, and how to set up BIM courses to meet the needs of the industry.

The opening of BIM courses in en gineering management colleges is also not optimistic in China. At present, the majority of engineering management colleges in China have offered BIM courses, the main way is to set up new BIM course, give priority to with BIM theory is introduced, added a 
small amount of BIM software operation. Most BIM related professional courses in most colleges and universities cannot integrate BIM technology into the existing engineering management system of professional knowledge, but they are just listed and stacked together, and the concept of BIM is thrown into confusion, or even just a simply think BIM technology is modeling. BIM technology itself is a coherent system, and it through in the whole process of engineering projects. At the present stage, the vast majority of colleges and universities is only to build BIM course for one-sided process, can not systematically build BIM course.

The lack of integration of BIM courses and existing professional courses, the narrow scope of BIM courses, the separation of theoretical teaching and practical practice, the big gap between the goal of talent training and the practical requirements, and the unsystematic teaching content curriculum system are all problems existing in engineering management colleges and universities.

In order to solve these problems, we need to integrate the teaching resources from the teaching content and teaching system, so that BIM technology can be properly integrated into the existing teaching mode of engineering management.

\section{Analysis on the Opening Principle of BIM course in Engineering Management Specialty}

In order to offer BIM course rationally, we need to analyze BIM course setting principle reasonably. First of all, we need to distinguish between the university level and the student level. Nowadays, engineering management colleges and universities are mainly divided into the higher vocational colleges, application-oriented universities and research universities. Different levels of schools require different teaching goals, in the higher vocational colleges, for example, cultivate skilled talents, which requires students to have a strong practical and hands-on ability. Therefore, we should give priority to the teaching of practical training and cultivate students' practical operation ability for the BIM course. In addition, we should distinguish the students' level. Students in the higher vocational colleges are weak in the theoretical foundation, and the ability of logical thinking is slightly low. We should teach students in accordance with their aptitude.

Secondly, we should take professional education as the base. The professional knowledge education of engineering management should be the foundation of our curriculum design, and on this basis, it is supplemented by BIM operation skills education. The BIM course is a supplement and continuation of professional education of engineering management, which provides services for better professional teaching. The content of the BIM course should be in accordance with the requirements of professional courses to meet the training objectives of engineering management specialty.

Thirdly, the setting of BIM course should persist the combination of theory and practice. BIM teaching should be closely integrated with practical projects, to meet the needs of the industry. The construction of BIM courses for engineering management specialty should consider two aspects of BIM theory and BIM practice. Besides theoretical knowledge learning, we should cultivate students' practical application ability of BIM technology.

Last but not least, BIM courses must be systematically embedded into the engineering management specialty training program. The curriculum of engineering management specialty runs through the whole process management of building engineering, so it is necessary to integrate BIM technology in the whole process so that students can know the application ideas and methods of BIM technology in different processes.

\section{Analysis on the Talent Training Ability Aims of BIM Course in Engineering Management Specialty}

The ability goal of engineering management requires students to have the basic ability of engineering project planning, design management, investment control, schedule control, quality control, safety management, contract management, information management and organization coordination ability in the engineering field, which requires the students to understand the knowledge map, construction and management. The core competencies of the engineering 
management major are engineering drawing and engineering management. That requires us to form two core competencies based on BIM talents training when embedding BIM courses: based on BIM software modeling capability and BIM engineering refinement management capability.

Based on the BIM software modeling ability, is to require students to be able to correctly read the construction drawings and convert them into the BIM model through the corresponding BIM software. In the process of capability training, visualization based on BIM, we first transform the engineering drawings into three-dimensional models to make the drawing recognition, and then through the modeling of BIM software to enhance drawing recognition and find the relevant correlation and deviation in the drawings.

Based on the BIM engineering refinement management ability is to configure the corresponding BIM software according to the the various components of engineering management, so as to make the management more refined and professional, and ultimately solve the comprehensive practical problems of engineering management with BIM technology. BIM technology can cover the whole process of meticulous management, thus forming a systematic teaching system and meeting the ability goal of engineering management specialty.

\section{Analysis on the Professional Course Setting in Engineering Management Specialty Based on BIM}

Engineering management specialty is an interdisciplinary, it combines civil engineering technology and management knowledge. Therefore, when setting up BIM courses, we should combine existing teaching plans with existing professional courses, rationally plan BIM curriculum system and arrange teaching sequence of BIM courses. At the same time, the engineering management major is a strong application, in our traditional teaching process, mainly with the teaching of theoretical knowledge, ignoring the engineering training or can not systematically carry out the engineering training, so we should take the BIM technology as a organic supplement of practice teaching, through professional course learning of theoretical knowledge combined with BIM skills training, developing BIM application skills.

The professional courses which can be embedded in BIM technology in the existing knowledge system of engineering management specialty include: architectural drawing, civil engineering construction technology, engineering project construction organization, construction engineering measurement and valuation, engineering project management, engineering bidding and contract management, etc. Therefore, combined with the characteristics of BIM technology to optimize the above courses and contents. Such as: architectural drawing course is mainly used in two-dimensional planar plane drawing teaching, poor intuition, for higher vocational students is difficult to understand the spatial structure of building. If the architecture drawing course embedded Revit software to form the three-dimensional building model, then it can enhance the students' ability of spatial cognition, and through the three-dimensional model of building recognition, and through the Revit software modeling, which can increase the students' cognitive ability so as to achieve the teaching effect.

In order to achieve the teaching goal, we should also carry out the corresponding BIM practical training courses in the above courses. BIM technology can provide students with a working environment that is closer to the engineering practice and can better achieve the on-site training effect. With the help of the BIM technology platform, taking a complete engineering case as a guide, through BIM practical training, the knowledge points of relevant courses in engineering management are connected together to form a complete knowledge system. The course of engineering management based on BIM technology is listed in Table 1. 
Table 1 the course in engineering management specialty based on BIM

\begin{tabular}{|c|c|c|c|}
\hline Course Name & Embedded BIM Technology & Training Course & Curriculum Effect \\
\hline $\begin{array}{l}\text { Architectural } \\
\text { Drawing }\end{array}$ & Revit & $\begin{array}{l}\text { BIM Modeling } \\
\text { Application }\end{array}$ & $\begin{array}{l}\text { Building three-dimensional } \\
\text { building models }\end{array}$ \\
\hline $\begin{array}{l}\text { Civil Engineering } \\
\text { Construction } \\
\text { Technology } \\
\end{array}$ & virtual simulation system & $\begin{array}{l}\text { Virtual simulation } \\
\text { construction training }\end{array}$ & $\begin{array}{l}\text { Virtual engineering construction } \\
\text { process }\end{array}$ \\
\hline $\begin{array}{c}\text { Construction } \\
\text { Engineering } \\
\text { Measurement and } \\
\text { Valuation }\end{array}$ & GGJ+GCL+GBQ & $\begin{array}{l}\text { BIM measurement and } \\
\text { valuation application }\end{array}$ & $\begin{array}{l}\text { Three-dimensional calculation and } \\
\text { engineering valuation }\end{array}$ \\
\hline $\begin{array}{c}\text { Engineering Project } \\
\text { Construction } \\
\text { Organization }\end{array}$ & Project+GCBV+BIM5D & $\begin{array}{c}\text { Construction } \\
\text { Organization Design } \\
\text { Training }\end{array}$ & $\begin{array}{l}\text { Compile network diagram, } \\
\text { Realize the three-dimensional } \\
\text { layout of the construction site, } \\
\text { Simulation demonstration of } \\
\text { construction and construction by } \\
\text { BIM5D }\end{array}$ \\
\hline $\begin{array}{l}\text { Engineering Bidding } \\
\text { and Contract } \\
\text { Management }\end{array}$ & $\begin{array}{l}\text { GBS+Glodon Electronic } \\
\text { Didding Tool }\end{array}$ & $\begin{array}{l}\text { BIM Bidding Simulation } \\
\text { Training }\end{array}$ & $\begin{array}{l}\text { Demonstration of the bidding } \\
\text { process }\end{array}$ \\
\hline $\begin{array}{l}\text { Engineering Project } \\
\text { Management }\end{array}$ & $\begin{array}{l}\text { BIM Project Management } \\
\text { Electronic Platform }\end{array}$ & $\begin{array}{c}\text { Project management } \\
\text { simulation training }\end{array}$ & $\begin{array}{c}\text { Demonstration of the whole process } \\
\text { of project management }\end{array}$ \\
\hline \multicolumn{3}{|c|}{ BIM5D Comprehensive Management Training } & Comprehensive Training \\
\hline
\end{tabular}

\section{Conclusion}

With the increasing application of BIM, the demand for the BIM application talents is also increasing. Colleges and universities of training talents should be have a clear understanding of the current trend of BIM technology and strengthen the cultivation of BIM technical talents. Therefore, we should take BIM as a means of teaching reform, strengthen the construction of the teaching staff, and attach importance to the cooperation between school and enterprise[6].

Engineering management is a complex specialty, and BIM technology should be used as a necessary professional skill for students. The teaching mode of engineering management based on BIM technology is still in the exploration stage. I hope this article can be used as a reference for BIM teaching reform, and also hope that the same kind of colleges and universities can exchange and summarize the teaching mode of engineering management based on BIM technology suitable for Vocational Education in China.

\section{References}

[1] National Institute of Building Sciences. United States National Building Information Modeling Standard, Version 1-Part 1: Overview. Principles, Methodologies[S]. (2007) 6-16.

[2] Ming SUN. UK national BIM strategy and its implementation[R]. ICCREM, (2014).

[3] Lu A. Worldwide IT Spending by Vertica 1 Market 2002 Forecast and Analysis, 2001-2006[R]. Framingham: International Data Corporation, (2002).

[4] W. Wu, R.R.A. Issa. BIM education and recruiting: survey-based comparative analysis of issues, perceptions, and collaboration opportunities[J]. Journal of Professional Issues in Engineering Education and Practice, 140(2014) 1-9.

[5] Jieh-Haur CHEN. Applications for big data in construction and real estate management[R]. ICCREM, 2014.

[6] E. Pikas, R. Sacks, O. Hazzan. Building Information Modeling education for construction engineering and management II: procedures and implementation case study[J]. Journal of Construction Engineering and Management, 139(2013) 1-13. 